Journal of the Scholarship of Teaching and Learning, Vol. 21, No. 2, June 2021, pp. 43-57. doi: 10.14434/josotl.v21i2.28090

\title{
Engaging Politically Disenfranchised Students in Governance
}

\author{
Esther Nir \\ New Jersey City University \\ Jennifer Musial \\ New Jersey City University
}

\begin{abstract}
New Jersey City University is an urban, Minority- and Hispanic-Serving Institution with a First-Generation-to-College, commuter, and immigrant student population. How can we engage our students who feel powerless, distrustful, or even threatened by government actors in governance? Will perceptions of governance change with increased exposure to political elites (e.g. judges, mayors, community board members) in their communities? Using Community Engaged Learning methods, we asked students to attend civic meetings and courtrooms to observe the inner workings of governance and engage in dialogue with political elites. Journals and surveys reveal that students deconstructed pre-conceived notions of powerlessness, humanized government actors, and became hopeful about change in their communities.
\end{abstract}

Keywords: higher education, community engaged learning, first generation to college, government, political elites.

"I can do this - I can make a difference. At least I have to try."

(Trial Advocacy and the American Legal System Student, Fall 2018).

How do we engage politically disenfranchised students in governance? Can community engaged learning (hereinafter "CEL") experiences empower students, some of whom are fearful of government and intimidated by political leaders, to engage in governmental functions (e.g. attend community meetings, participate in social justice reform, assume leadership positions) even if they enter the experience with deep rooted personal perceptions that they are powerless to effectuate positive change? As academics teaching at New Jersey City University (hereinafter "NJCU") with a large population of students from socio-economically disadvantaged backgrounds, we aspired to try. Using two courses from different disciplines (Criminal Justice and Women's and Gender Studies), we placed our students in government spaces (i.e. courtrooms, civic meetings) to observe and journal their experiences. Our goal was to demystify the players and processes in force; we hypothesized that front row seats to these important proceedings (trials, hearings, civic meetings) might enhance student understanding of governmental functions, familiarize students with political elites ${ }^{1}$ and other governmental employees (e.g. court officers, clerks), and inspire students to envision their potential future roles in governance. In order to evaluate our progress, we collected data via pre- and post-

\footnotetext{
${ }^{1}$ We take Charles Mills' (2000) concept of the "power elite", the privileged few who make key socio-legal, economic, and political decisions for a community, and modify it into the political elite, to refer to those who work in governance. Examples might include elected or appointed governmental officials (e.g. judges, mayors), community board members, and other persons with the power to influence governmental policies and practice (Nir, 2017). See pp. 11-12 for a more detailed discussion.
} 
learning surveys and student journals. In this article, we share our strategies to engage students as well as our evaluation of their effectiveness.

This article begins with a description of our institution and participating student demographics. We then provide pre-learning survey results to establish a baseline for student perceptions prior to our courses. Following brief course descriptions and a literature review, we share results from our post-learning survey and qualitative analyses of student journals. The article concludes with a discussion of the value of using CEL strategies to engage socio-economically disadvantaged undergraduate populations in governance.

\section{Institutional Description}

NJCU is a public liberal arts institution that educates over 9,000 students in the urban Northeast. The campus draws a majority commuter population (97\%) that resides in and around Jersey City, New Jersey. NJCU charges the lowest tuition in the state, which appeals to students who are working class and working poor. The school is a Minority-Serving and Hispanic-Serving Institution located in one of the most diverse cities in the United States: $40 \%$ of students self-identify as Hispanic, $23 \%$ as Black/African-American, $20 \%$ as White, $8 \%$ as Asian, and finally $8 \%$ fall into the "Missing Data/Other" category (Gerber, Personal Communication, October 23, 2018). In 2017, 57\% were First Generation to College students (Gerber, Personal Communication, October 23, 2018). While no data on immigration status has been collected by the university, anecdotally we know many students come from immigrant families, perhaps even being immigrants themselves, and, for a sizeable population, English is their second (or third) language.

\section{Study Demographics}

We collected student demographics via surveys. Of those who completed the post-learning survey, $57.1 \%$ self-identified as Latinx/Hispanic $(n=44), 20.8 \%$ as Non-Latinx/Hispanic, White or Euro American ( $\mathrm{n}=16), \quad 14.3 \%$ as Black/Afro-Caribbean/African American ( $\mathrm{n}=11), 6.5 \%$ as Indigenous/Native American/Pacific Islander $(n=5), 5.2 \%$ as Bi/Multi-racial, and 3.9\% equally as South Asian, East Asian, Middle Eastern or Arab, and Another Category Not Identified ( $\mathrm{n}=3) .{ }^{2}$ The majority of students have a connection to immigration: $40.3 \%(n=31)$ have at least one immigrant parent while $24.7 \%(\mathrm{n}=19)$ are immigrants themselves. $58.4 \%$ did not identify as a First Generation to College student $(n=45)$ while $40.3 \%$ did $(n=31)$, with $1.3 \%$ preferring not to answer $(n=1)$. The majority of students $(94.8 \%)$ are under the age of 25 .

\section{Pre-Learning Quantitative Findings}

We used a pre-learning survey to glean information about civic participation. Students responded to two prompts: "I volunteer in my community" and "I have spent time in the court system and/or municipal government offices before taking this class." We were interested to learn about their participation in community spaces as a marker of civic participation over more traditionally defined engagement (e.g. voting). We learned that $58 \%(n=58)$ of students are volunteering their time. We also ascertained that $93 \%(n=93)$ of students have spent little time in governance spaces. With this data, we surmised students were stepping outside of their comfort zones upon entering civic spaces and engaging with political elites.

\footnotetext{
${ }^{2}$ All survey respondents were able to choose multiple racial and ethnic identity categories.

Journal of the Scholarship of Teaching and Learning, Vol. 21, No. 2, June 2021. josotl.indiana.edu
} 
At the start of the semester, we wanted to establish how much students knew about issues in their community. Using a Likert scale, students responded to: "I am aware of my community's needs and concerns". Responses indicate that the majority of students were either unsure or had some familiarity with issues in their communities. Next, we wanted to determine how much students knew about civic decision-making. Here students responded to: "I know how decisions are made that affect my community (i.e. local courts; municipal government)". We learned that over 1/3 knew how decisions were made, but nearly half the class was uncertain or said they did not know about the decision-making process in their community.

Since many students come from marginalized backgrounds, we were curious to assess their trust in governance. We prompted: "I believe the court system and/or municipal government runs smoothly and without bias or prejudice." The majority of students $(52 \%, n=52)$ answered with a negative metric (i.e. Strongly Disagree or Disagree) while $1 / 3$ were neutral, perhaps indicating that they were not sure or felt the answer was more complicated. No students strongly agreed with the statement. Finally, we asked about comfort with political elites: "I feel comfortable communicating/ interacting with representatives in the court system (i.e. judges, clerks, lawyers, etc.) and/or municipal government (local elected representatives, employees at city hall, etc.)." We learned that 39\% of students felt relatively comfortable with political elites but nearly the same number felt neutral, indicating no feelings or complicated feelings about political elites. We acknowledge that even with an anonymous survey, some students may have felt uncomfortable with the question so they chose neutral as their response. Over 1/5 of students felt some discomfort around political elites. Through this data, we discovered that many NJCU students are uncertain, uneasy, and maybe even distrustful of systems of governance and political elites in their communities. Given that the overwhelming majority of students have not spent time in civic spaces, we hypothesized that they form their perspectives about political elites through local news, friends, family, or the effects of governance decisions on their lives. This increased our curiosity about how students would respond to physically visiting these sites.

\section{Courses Utilized}

Students were drawn from two courses: Trial Advocacy and the American Legal System and Diversity and Difference. Below we discuss each, in turn.

\section{"Trial Advocacy and the American Legal System."}

"Trial Advocacy and the American Legal System," offered by the university's honors program, explores the role, structure, and function of the American court system. The course focuses on adversarial processes and the roles played by court actors including judges, prosecutors, defense attorneys, juries, defendants, and victims. Students engage in numerous classroom simulations of various trial stages including jury selection, opening statements, direct and cross-examination of witnesses, closing statements, and sentencing proceedings. The course culminates in a full mock trial experience in a State Superior Courthouse with a Superior Court judge presiding. This course is offered exclusively to sophomores in the university's honors program (two sections of the course are offered each fall semester).

During the Fall 2018 semester, 25 students were enrolled in one section and 22 students were enrolled in a second section (47 total). In addition to classroom instruction, students traveled to a courthouse of their choosing and observed 10 hours of court proceedings. Students were provided with the choice to attend either the Jersey City Superior Courthouse or a courthouse in their own communities. While some students preferred to travel from campus to the Jersey City Courthouse in

Journal of the Scholarship of Teaching and Learning, Vol. 21, No. 2, June 2021. josotl.indiana.edu 
small groups, others found it more convenient to attend proceedings closer to their homes. Assistance in locating and traveling to courthouses were provided to students on a regular basis. Further, updates on ongoing cases, hearings, and trials at the Jersey City Superior Courthouse were sent to students, via email, by the supervising judge. Students were permitted to travel to the courthouse on their own or with their classmates; with the exception of one class period, observations took place on the students' own time. Students were taught to journal their observations and create field notes, including their perceptions, opinions, feelings, and concerns associated with their court visits. After the observation hours were completed, students formed groups to compare their observations and share their various perspectives. Students also had the opportunity to engage in question/answer sessions with judges and were encouraged to openly express their feelings - positive or negative - regarding their observations. Professors and judges consistently assured students that they should feel free to express any thoughts or questions and students had the opportunity to show their questions to the professor in advance. Students were thoughtful in their questions and freely addressed a myriad of "hard" issues including racial discrimination, nepotism, and ethical conflicts. At the conclusion of the course, each student group, consisting of three or four students, led a "debriefing" classroom discussion in which they discussed their collective experiences, and compared and contrasted each group member's individual impressions and observations. Each group drafted a letter to the judiciary describing their perceptions and providing suggestions to improve case processing.

\section{"Diversity and Difference."}

"Diversity and Difference," offered by the Department of Women's and Gender Studies, explores how power materializes through individuals, interpersonal relationships, and socio-political institutions. "Diversity and Difference" teaches about privilege and oppression on micro as well as macro levels. A significant course goal is to build cultural humility while teaching other essential skills that help students navigate diverse workplaces, communities, and social interactions. "Diversity and Difference" is a 100-level General Education course that fulfills the Civic Engagement and Intercultural Knowledge learning objective at NJCU. There are multiple sections of 25-30 students who enroll anytime between their first semester and senior year. To achieve our CEL goal, students observe governance in their communities by attending three civic meetings throughout the term (i.e. City Council, Board of Education, Rent Control, Transportation Board, etc.). Early in the semester, the professor guides students to peruse the websites of their town and journal about their impressions. Students are asked to consider whether the information is current, visually appealing, representative of their community, and easy to find, which leads to a larger analysis of accessibility. At the end of class, students choose which meetings to attend based on scheduling needs and interests (e.g. an aspiring teacher is encouraged to visit Board of Education meetings). ${ }^{3}$ Students attend meetings on their own time, but some exceptions are made for students to use class time when the course is taught in the evenings. They are encouraged to find a "class buddy" if they have chosen the same meeting as a classmate, which happens for roughly $50 \%$ of the class. Students journal their experiences and write a 400-word reflection based on guided prompts for each visit. Students are given feedback on their writing to deepen their analysis and some time is spent debriefing in class particularly when there are patterns in student observations or an issue that is relevant to the class arises (e.g. county officials debating ICE contracts). The prompts deepen over time leading students to reflect on whether the

\footnotetext{
${ }^{3} \mathrm{~A}$ few students were hesitant to complete the assignment because they recently moved to their community. In nearly every case, students moved one town over. In these situations, students were allowed to visit civic spaces in their new community or their previous one.
}

Journal of the Scholarship of Teaching and Learning, Vol. 21, No. 2, June 2021. josotl.indiana.edu 
elected officials or board members represent the community's best interests. The course concludes when students write a letter to an official they observed in action alongside a longer reflective paper on progressive social change and community leadership.

\section{Literature Review}

Good Citizenship

Engagement is central to good citizenship. Defined this way, citizenship is demonstrated by what one does: it is an action, not an identity or status (Mirra \& Garcia, 2017). In a recent Pew Research Center survey, Americans affirmed that actions like voting, paying taxes, and abiding by the law are the top three features of good citizenship. However, youth do not place the same value on voting: only $56 \%$ of those under 30 believe voting is the most important marker of citizenship (Gramlich, 2019). ${ }^{4} \mathrm{~A}$ mere $11 \%$ of college students go beyond voting to "participate in a government or political organization or issue" (Benenson \& Bergom, 2019, p. 1667). Johnson and Ferguson (2018) found that college seniors and recent graduates view politics as too messy and divisive. Even if they have a strong civic identity, students sidestep conversing about politics to avoid conflict. Youth are more disinclined to vote or talk about politics; they are skeptical of American democracy as well.

There is a reason why young people are less likely to engage in "good" citizenship like voting, political participation, or political discourse. After the 2016 election, nearly $1 / 3$ of millennials doubted the health of the U.S. democracy. This apprehension was most felt by young voters of color: nearly half of Black millennial voters reported losing faith in U.S. democracy while over $40 \%$ of Latinx voters felt the same (The Center for Information and Research on Civic Learning and Engagement 2017). Despite low participation rates and lost faith in governance systems, marginalized youth are civicallyengaged in other ways. Godfrey and Cherng (2016) contend that young people from low socioeconomic areas, especially Asian-American and Black youth, place a high importance on helping people in their communities. Students of color spend time volunteering in ways that do not typically count as volunteerism, such as helping a cousin with homework, driving a neighbor to medical appointments (Mitchell, Donahue, \& Young-Law, 2012), or serving at their place of worship (Green, 2003). Rockenbach, Tuchmayer, and Hudson (2014) posit that marginalized students reframe civic engagement as "giving back" rather than acts of citizenship or political inclination. While marginalized young people may not be engaging in traditional ways, they are flourishing in digital and online environments where they can participate in politics rather than Politics (Mirra \& Garcia, 2017) by interacting with official organizations, community leaders, and political candidates (The Center for Information and Research on Civic Learning and Engagement, 2018b).

\section{Politically Disenfranchised Students and Curricular Civic Engagement}

Civic engagement courses can re-invigorate youth participation in democracy; however, research on low-income, first generation, and/or racialized students in civic engagement courses is relatively scarce. Most studies centralize a normative profile: the white, middle to upper-middle class, continuing generation, 18-22 year old, able-bodied, residential college student without dependents who takes a civic engagement course (taught by a white faculty member) to serve low-income and/or racialized

\footnotetext{
4 The youth vote peaked for the 1972 presidential election and midterm voting has been on a slow decline since 1972. Youth midterm election participation jumped in the 2018 election to 31\%, the highest turnout in 25 years (The Center for Information and Research on Civic Learning and Engagement 2018a). Time will tell if this continues.
}

Journal of the Scholarship of Teaching and Learning, Vol. 21, No. 2, June 2021. josotl.indiana.edu 
communities (Butin, 2006; Doerr, 2015; Green, 2003; Mitchell, Donahue, and Young-Law, 2012; Pearl \& Christensen, 2017b; Téllez, 2000). Low-income, first generation, and/or racialized students are just as interested in civic engagement as other students. Pearl and Christensen (2017a; 2017b) found that marginalized students are more altruistically-motivated than their peers yet fewer enroll in elective civic engagement courses. Téllez (2000) reminds that civic engagement comes with "opportunity costs" such as needing to quit jobs, skip classes, or devote the extra time. If marginalized students know they can be altruistic outside of school, there is less buy-in for the courses (Pearl \& Christensen, 2017b).

Low-income, first generation, and/or racialized students may be wary of what civic engagement offers, but research shows that they benefit from taking these classes. There are positive correlations between civic engagement and increased GPAs, retention, and overall comprehension of subject matter for low-income, first generation, and/or racialized populations (Kanwischer, Lilgreen, \& Saralampi, 2015; Yeh, 2010; York, 2016). Thus, under-represented students have the biggest intellectual gains to make from a civic engagement course. Cadelario (2018) argues this is because under-represented students experience the biggest gap between collegiate learning and the communities they come from so "when students understand the power of academic knowledge to transform their worlds, their personal investments in their education feel not only much more justified, but absolutely necessary" (p. 183). For low-income, first generation, and/or racialized students, the ability to "bridge' their communities of origin with their academic communities" may bring coherence to "two disparate worlds" (Conley \& Hamlin, 2009, p. 48).

The interaction between two worlds is a common feature of civic engagement. The metaphor of crossing a border is used to explain the value of getting students out of their comfort zones. Many argue that when students interact with people who have different daily realities and worldviews, they will develop perspective-taking, non-judgment, and compassion (Astin et al., 2000; Eyler \& Giles, 1999; Naudé, 2015; Simons \& Cleary, 2006; York, 2016). Ideally, students move beyond "tolerance" towards empathy.

\section{Political Elites in the Community}

This approach to civic engagement presupposes a student has some social-location privilege whereas the "served" population is under-resourced and marginalized (Butin, 2006; Doerr, 2015; Mitchell, Donahue, \& Law-Young, 2012). What happens when students are engaging with elite members of their community? Mills (2000) introduced "power elite" to refer to a concentrated group of people who "have a greater share than other people of the things and experiences that are most valued" (p. 9). While the power elites are at the top of the socio-political-economic hierarchy, Mills recognized that professional politicians constitute the middle level of power because they carry out the work of the power elite. In a local context, these political elites operate as a "set of cliques or 'crowds' whose members judge and decide the important community issues..." (p. 36). For this study, we define political elites as people charged with ensuring the functions of governance, such as judges, lawyers, court officials, mayors, city counselors, and board members. These community members are meant to represent their constituents; yet, they hold more socio-political power to make decisions that affect their communities. They can be intimidating based on the level of influence they can, and do, exert. Mirra \& Garcia (2017) argue that "negative contact with public officials can have a dampening effect on the willingness to participate in public life" (p. 143). Marginalized students may enter the classroom strategically disengaged with public officials based on previous negative interactions (Mirra \& Garcia, 2017; Taylor \& Baker, 2019). Our unique circumstances provided a good opportunity to test whether students could find common ground with political elites, and whether the goals of perspective-taking, non-judgment, and compassion would hold given this power dynamic.

Journal of the Scholarship of Teaching and Learning, Vol. 21, No. 2, June 2021. josotl.indiana.edu 


\section{Data \& Methods}

Data for this study were drawn from student journals $(n=80)$ chronicling observations of government proceedings as well as pre- $(n=100)$ and post- $(n=77)$ learning surveys. We adapted the Longhorn Center's (The University of Texas-Austin) Community Engagement Pre-Course Survey and we drew from Gelmon et al.'s (2001) Assessing Service-Learning and Civic Engagement: Principles and Techniques to create the surveys. In total, 100 pre-learning surveys and 77 post-learning surveys were completed in Fall 2018 and Spring 2019. All surveys were filled out anonymously. 56\% of the pre-learning surveys came from Diversity and Difference $(n=56)$ while $44 \%(n=44)$ came from Trial Advocacy and the American Legal System. 53.3\% of the post-learning surveys completed were from Trial Advocacy and the American Legal System $(n=41)$ while $46.7 \%$ were from Diversity and Difference $(n=36)$. Substantive questions pertinent to this study included gauging awareness of the needs and concerns in one's community, knowledge of community decision-making, trust in governance, and comfort interacting with political elites (i.e. judges, attorneys, mayors, city council members etc.)

Data was also drawn from student journals documenting their observations, including related perceptions, opinions, and feelings. 42 of the 47 honors students consented to have their journal included in this study. The remaining 38 journal entries were drawn from students enrolled in Diversity and Difference. To analyze the data, an inductive, grounded theory approach was utilized to develop theoretical categories that "place the data into a more general or abstract framework" (Maxwell, 2005, p. 97). Numerous themes emerged during data analysis including demystification of political elites following direct exposure, increased feelings of empowerment to engage in governance, among other themes. Data from each journal analyzed was compared to the next journal; themes were consistently refined to reflect the complete body of data collected.

\section{Methodological Limitations and Future Directions}

A few methodological limitations warrant mention. First, the "Trial Advocacy and the American Legal System" course was offered exclusively to honors students; in this regard, this portion of our data captures the perceptions and feedback of a pre-selected group of students on campus. Future studies should sample courses open to the broader community of students to ascertain how, if at all, academic level and course rigor may influence student response to these experiences. Second, our data does not capture potential cultural differences among courthouses; future studies should examine how local court context affects student perceptions and experiences. Next, while our study is interdisciplinary, it is limited to students from two courses related to governance. Future studies should explore how our findings hold among a wider range of disciplines as well as other community-based locations (e.g. immigration organizations, social justice institutes). Finally, when we asked students about their knowledge of civic spaces, we did not take into account how long they lived in their current community. Anecdotally, we know that the vast majority of our students did not move to new communities. Further, the few students who were unfamiliar with their new surroundings were allowed to visit civic spaces in their previous communities (see p. 8, footnote 3). Future studies should explore how length of residency within a community may influence students' knowledge about their local civic spaces.

Journal of the Scholarship of Teaching and Learning, Vol. 21, No. 2, June 2021. josotl.indiana.edu 


\section{Results}

\section{Post-Learning Survey Quantitative Findings}

We asked questions to ascertain whether students felt more knowledgeable about their communities as well as more trusting of, and comfortable with, political elites after their civic meeting/courtroom visits. When asked if they were more aware of their community's needs and concerns, the affirmative metrics increased while those answering "Neutral" or any range of disagreement decreased. Importantly, the greatest increase was in the "Strongly Agree" category, which went up by 15\%. We took this as a positive sign that students felt more knowledgeable about their communities after civic space visits. We were curious to know whether these experiences taught students about the decisionmaking processes in their communities. By the end of the course, the "Strongly Agree" metric jumped from $10 \%$ to $16.9 \%$, the "Agree" metric rose too from 34\% to $59.7 \%$ while the "Neutral", "Disagree", and "Strongly Disagree" responses all went down. We concluded that students left with more clarity about community decision-making.

In the pre-learning survey, it was evident that students did not trust governance processes or political elites. When we asked students if "the court system and/or municipal government runs smoothly and without bias or prejudice”, after spending time observing civic environments, students' answers changed. Now, $3.9 \%$ of students felt very confident in the system while $11.9 \%$ felt confident. "Neutral" responses rose 8\% too. The "Disagree" category saw a slight rise. Significantly, while 27\% said they "Strongly Disagree" with the statement at the beginning of the semester, only 9.1\% of students answered this way on the post-learning survey. Overall, it appears that students felt more confidence in these governance processes. Finally, we wanted to know if students now felt more comfortable with political elites. On the post-learning survey, students expressed a rise in comfort engaging with civic representatives. While the "Strongly Agree" category went down 6\%, the "Agree" category went up $12 \%$. Students answering "Neutral" remained the same. Both "Disagree" and "Strongly Disagree" metrics went down by the end of the semester. Results indicate that these CEL experiences enhanced student comfort with political elites in their community.

\section{Student Journals}

In this section, we report the descriptions, perspectives, and analyses recorded by students in their observation journals. Overall, these journals demonstrate that attending government proceedings leads to a fuller and more nuanced understanding of the players ${ }^{5}$ and processes in force, empowering student to engage in governance.

Demystifying the players. During their visits to a courthouse or civic meeting, students observed and interacted (at times) with players in their professional environments. These experiences provided students with the opportunity to learn about players on relatable levels. In some cases, formerly intimidated students grew more comfortable with players; in other instances, student perspectives evolved through direct exposure to these political/government actors. In this section, we explore the ways in which these experiences demystified players in students' eyes, dispelled inaccurate preconceived notions, and fostered a comfortable sense of familiarity. Areas explored include student observation and analysis of (1) players' daily activities; (2) relationships and interactions between players; (3) body language; and (4) direct interactions between students and players.

\footnotetext{
${ }^{5}$ In this article, "players" refers to political elites (e.g. judges, mayors, council members), government actors (e.g. attorneys, court officers, police officers), and other individuals regularly engaged in government proceedings.

Journal of the Scholarship of Teaching and Learning, Vol. 21, No. 2, June 2021. josotl.indiana.edu
} 
Students relate to players' daily activities. Students described government actors engaged in ordinary and familiar actions, such as using their cellular phones, planning lunch, or simply joking around with colleagues. Commonly, students seemed amazed to see players engage in these typical human interactions and conversations. For example, one student noted: "While standing behind me two officers talked about trying the new Buffalo sandwich from the Blimpie's during their lunch break" (21), and another mentioned that "there had even been a few attorneys sitting in the back just discussing recent movies" (17). A third student was surprised by a conversation between a judge and prosecutor during a break in the proceedings: "Judge $[\mathrm{X}]$ and the prosecutor started talking about Rutgers basketball while they waited" (8). Others focused on the use of humor by courtroom actors: "The officer was then asked to handle evidence, so the prosecutor asked for gloves for him. He struggled to put the gloves on so he, Judge $[\mathrm{X}]$, the attorneys, and the courtroom assistants began laughing because they were too small" (8). Another student noted that "the judge joked around, even making a joke about the typist being a rookie so the attorneys should speak slowly" (13).

Students notice relationships/interactions between players. In addition to observing individual behaviors and actions, students observed players interacting with one another. Several students commented on the 'comfortable' exchanges between players: "Everyone seemed very familiar with each other. It seems that they all spend a lot of time in the court" (1). A majority of students highlighted positive interactions and relationships in their journals. For example, several students took note of judges" positive exchanges with various individuals in the courtroom: "As the witnesses and defendant took the stand, the judge greeted them and offered them something to drink" (6). And another student noted: "The judge humanizes himself through his interaction with the jury because he was very open with them as if they were his own friends and family" (13). Similarly, students observing Town Hall and/or Board of Education meetings described productive exchanges between residents and town council members: "The council cares about the town so much and about its residents. There is no divide, both the council and residents work together to come up with solutions to their problems. The council listens to the community instead of ignoring them" (66). In contrast, more than half of the students observed at least one negative interaction - such as rude or disinterested behavior - that resulted in unproductive proceedings: "Councilman $\mathrm{X}$ finally decides to say enough is enough. At that point, she was met with a rude council woman claiming that her time to speak was up" (43).

A handful of students were surprised by the positive interactions between players with opposing roles; several students re-evaluated their preconceived notion that professional adversaries have contentious relationships: "The defense and prosecution attorneys engaged in conversation with the audience and between themselves. This made me reconsider my previous conclusion about the relationship between the defense and prosecution attorneys" (5). Similarly, other students focused on the 'surprising' personal connections between courtroom rivals: "The attorneys agreed to eat lunch together. They had each other's phone number and they keep in touch. There's no hard feelings after the case" (33). Surprised student reactions (to pleasantries between 'adversaries') were not limited to opposing counsel. For example, a few students were 'shocked' to see positive interactions between defendants in custody and court officers: "The most shocking part of it all was seeing the court officers interact with the defendant. The majority of them treated him as if he was another person in the room, with some restrictions, of course. But they even laughed with him occasionally while waiting for the judge to return to his chair" (21). In contrast, a few students noted somewhat negative interactions between opposing courtroom actors: "The defense attorney tried to make conversation with the prosecutor, but she ignored him and walked out of the room" (5).

Students observe body language. Students paid close attention to the body language of various players; attention to non-verbal communication provided students with a fuller picture of the

Journal of the Scholarship of Teaching and Learning, Vol. 21, No. 2, June 2021. josotl.indiana.edu 
personalities, emotions, and social environment in the room. For example, a few students described body language indicating tension or nervousness: "The prosecutor kept licking his lips so aggressively which was a little disturbing" (11). And another noted: "One of them, the last one to present, spoke too fast, barely hearable and seemed as if he was nervous" (23). A few students focused on the general 'feel' of the room: "The audience seemed extremely tense regarding this proceeding, while the attorneys were not anxious at all" (17). In contrast, other students described body language indicating a relaxed environment: "All the attorneys as well as the judge are smiling and laughing" (13).

Several students differentiated between the body language of different players present at the same proceeding: "I looked to see the reaction of the council members and many were smiling but there were one or two who were not as amused" (80). A few students interpreted body language as a sign of impatience or disapproval by certain players. For example, one student noted: "Judge [X] seemed like she was not having any of the attorney's shenanigans. She was very sassy with her hand smushed against her cheek and elbow placed on the desk. She had an expression on her face of boredom but also of tiredness" (12). Finally, other students concluded that certain players consciously use nonverbal communication for strategic purposes: "The defense attorney create[d] a motherly effect to gain sympathy from the jurors. She touched Mr. $[\mathrm{X}]$ on his shoulders to convey more of this motherly or caring vibe onto the audience" (28). These and other similar observations display a somewhat nuanced and sophisticated understanding of players and their behavior.

Interactions between players and students. A majority of students reported a positive interaction (e.g. kind, engaging and helpful players) they experienced with a player at least once: "When in the lobby, I had barely mentioned that I was there for our class and immediately an officer informed me of the current trials going on and offered me directions to them" (4). A handful of students appreciated a criminal court judge's attention: "The judge took some time to speak with the four of us that were observing the trial...He said he was happy to be able to be speaking with some future leaders of the country" (38).

Demystifying the process. During their observations, students witnessed a variety of governmental processes in action. For most, these experiences illuminated the 'real life' mechanics of the observed proceeding. For example, a student observing a Board of Education meeting reported: "This has opened my eyes to the inner workings and dynamics of how the schools really run in my town" (49). Students relayed particular procedures they learned during their observations; examples include judicial processes in the courthouse, treatment of defendants, the role of court clerks, sidebars procedures, and the role of council members at board meetings, among others. At times, specific processes left strong impressions on students: "Even though he was going to be released, [the defendant] still had to remain shackled to the other detainees and go back to the jail to get his belongings. I see the purpose in this, but it also feels like there could be a better system in place for individuals who are going to be released" (8).

Fairness of the process. About half of the students noted that the process appeared fair to all involved: "My city is always willing to help anyone in my community. The diverse race and gender sitting at the table shows that they do equal treatment for everyone who lives in [X] City" (58). Another student commented on the fairness of a judge she observed in criminal court: "Very fair judge with a lot of experience under his belt...he treated those charged with crimes with respect, and he even took into account their situations outside of the crime they committed like their employment status or Section 8 housing" (12). In contrast, approximately one third of the students perceived unfair favoritism or prejudice toward certain individuals or groups: "The council members used their white and male privilege to make decisions for a racially diverse community. There was only one white female there at the meeting and she hardly had a say in any big decisions" (68). Another student was concerned about nepotism on a community board: "Many of the people on the boards and elected official positions are there because they are related or are friends with those already in power which is

Journal of the Scholarship of Teaching and Learning, Vol. 21, No. 2, June 2021. josotl.indiana.edu 
unfair. This doesn't give the opportunity for other people to join and offer different perspectives. If you want to move up the social ladder then you need to have the connections" (49).

More respect needed. About a third of the students were critical of behaviors that demonstrated a lack of respect for the process. For example, a few students expressed their disapproval for the way that people dressed for court: "I noticed that some people are dressed casually to appear in front of the judge. Some people wore jeans, and some had sweatpants that were sagging very low. I just thought it was a very bad image, even though image is not supposed to be taken into account" (1). A few others commented on the tardiness of courtroom actors: "One of the lawyers was almost 30 minutes late - it surprised me that we waited for him to arrive for so long without a threat of postponing the hearing or even seeing the other case that was waiting" (23). Other students focused on disrespectful verbal communications between attendees at a town hall meeting: "Those few that did speak up about their opinion for the project were given boos and even one lady came up to another and began arguing with her, about how she is making a mistake and that she is going to surely regret it" (78). It was interesting to note that, in some instances, students appeared to respect the government process more than the players.

Analyses of performance/effectiveness of players. Students provided their perspectives on the effectiveness of various players during government proceedings. For example, many students observing courtroom hearings and trials criticized the advocacy techniques and skills of the attorneys: "The prosecutor presented her entire case and from the two days I had attended the trial it seemed as if she was not meeting the burden of proof. For every argument or fact to be presented, the defense steered the jury in another direction. He more than caused reasonable doubt, often times destroying the evidence she presented almost completely" (21). In contrast, other students were impressed by strategic decisions made by courtroom advocates: "I was watching the cross-examining attorney whenever he would choose to sit down or stand up. I noticed that whenever he would sit down, it seemed like he was establishing power and using his pen to point towards the defendant to acknowledge him" (1). The majority of students were impressed by political elites' (i.e. judges, board members, mayors) management of government proceedings. For example, one student stated: "At the end of the day the Board does try to accommodate and make decisions that are acting in the community's best interest. The fact that there was a compromise to waive the ordinance during discussion on ICE [Immigration and Customs Enforcement] does show that Board members want to give the public a fair chance at stating their views" (76).

Empowering student to engage. Nearly $25 \%$ of students noted that their observation experiences sparked a desire and/or empowered them to engage in governance in their communities. Students described this sentiment in different ways. One student noted that, "sitting in the courtroom there, I thought that I honestly wouldn't mind having a job as an official in the courthouse" (17) and another stated: "I will want to run for public office in my community one day, and I will volunteer any day to sit on my community board, I think I have much to contribute...As a [B]lack [person] seeing a lot of [B]lacks in the local level, it makes me want to work harder" (44). A handful of students even referenced their responsibility to engage in governance. One student stated: "I feel like I do have a responsibility to create positive change in my community...I really want to help...I know I can be an ally" (45).

\section{Discussion and Conclusion}

The challenge of engaging politically disenfranchised students in governance is complex; difficulties arise not only from students' current situations but, also, from a myriad of prior life experiences that shaped their perceptions, opinions, and philosophical beliefs about government long before they embarked on their undergraduate careers. Some students who enter the academic environment from

Journal of the Scholarship of Teaching and Learning, Vol. 21, No. 2, June 2021. josotl.indiana.edu 
socio-economically disadvantaged communities have had negative interactions with government actors; indeed, history has shown that certain groups and communities are the subject of disparate treatment by police (Brunson \& Miller, 2005; Carbado, 2017). As of September 2020, the recent deaths of George Floyd, Breonna Taylor, Tony McDade, and others legitimize distrust of police and other government officials. Others have experienced the damaging effects of mass incarceration and its profound impact on their communities (Clear, 2008). Even students with limited or no exposure to government actors or processes often possess preconceived notions, based on secondary information from family and friends, of powerlessness to create change and the futility of engagement in government. Lack of exposure or negative exposure with governance allows feelings of hopelessness to grow and sentiments of powerlessness to crystallize.

Civic engagement courses help young people channel hopelessness and powerlessness into action. Politically disenfranchised students, or what \#BlackLivesMatter co-founder Alicia Garza calls "the new American majority", are an untapped, and often disregarded, population of civic actors because political strategists often assume they are passive non-voters (Garza, 2019). However, if the 2018 midterms are any indication, young people are fired up. They are demanding attention (Black Youth Project, DACA students, the March for Our Lives, and calls to Defund/Abolish the Police are but a few examples here) and insisting on having a seat at the table. Our students may come to our CEL classes thinking politics is "not about me or for me", but they have the potential to re-shape the future of U.S. politics: local governance is an ideal space to practice change-making because it is where one can see change immediately.

Like political strategists, civic engagement researchers have neglected the perspectives of disenfranchised students. The dominant model of civic engagement involves students with some degree of privilege entering marginalized spaces or communities to carry out a "service" project. Our research is unique because it centralizes low-income, first generation, and/or racialized students who are living in, and engaging with, their own communities. In our project, the Other is a member of the political elite (e.g. judges, lawyers, mayors, city council members) who holds decision-making power that affects students' lives or government employees who work directly in these systems (e.g. court officers, clerks). Our study points to the power of exposure to governance spaces; while we acknowledge that exposure to political environments is not sufficient to increase political participation in and of itself (Johnson \& Ferguson, 2018, p. 523), our research shows that it is a crucial first step for disenfranchised students to be able to see themselves reflected in political elites and other government employees. Intentional course scaffolding can build on this by helping students to embrace a civic identity and commitment to social change.

Analyses of student journals and our post-learning surveys reveal that (in most cases) student observations of courtroom proceedings and civic meetings result in a profound demystification of government players and processes. Perhaps the most notable theme emerging from these data is our students' realization that political elites (e.g. judges, mayors) and government actors (court officers, citizen activists) are human too because they share similar apprehensions, insecurities, and weaknesses to those experienced by students. They also engage in familiar routines (e.g. deciding what to eat for lunch), enjoy leisure activities (e.g. sports), make mistakes, get nervous, and become overwhelmed; sometimes they succeed and sometimes they fail. Instead of remaining elusive characters that appear unapproachable, they became familiar figures to whom students can relate. Moreover, many students had positive exchanges with players; certain players, such as judges, assumed mentoring roles and went out of their way to reach out to students. For some, 'the judge' came to represent a supportive figure they admired, a sharp contrast to some students' preconceived ideas that judges are unfair political elites who operate with prejudice and bias.

In addition to demystifying the players, student journals demonstrated that these experiences familiarized students with the processes at play; journals document new substantive knowledge of key

Journal of the Scholarship of Teaching and Learning, Vol. 21, No. 2, June 2021. josotl.indiana.edu 
processes (e.g. how civic meetings are organized, trial orders). More significantly, being in these spaces sparked critical analyses (e.g. "Sidebars do not make sense. They are just distracting"). Students noted perceived shortcomings in the proceedings (e.g. people talking over each other at civic meetings) and envisioned potential change. Some students even perceived their own potential contributions to making these imagined changes into a reality. Demystifying political elites and governance processes does not resuscitate them. Seeing elites as human does not absolve them of damaging decisions that disproportionately affect the communities where many of our students reside. If anything, students become better critical thinkers through demystification because it exposes systemic and human flaws while giving students concrete examples. Demystification also empowers students to use the system to advocate for change. For example, we hope they are more likely to speak up at a civic meeting because they are less afraid to walk into City Hall chambers, a formerly foreign space, and now know how to get on a Speaker's list.

In the pre-learning survey, we learned that the majority of students entered civic environments feeling pessimistic about perceived biases and/or prejudices in courts and governance systems. Our goal is to invite students to approach civic engagement with "critical hope", which is an ethical responsibility that embraces the "necessary tension between criticality - of privilege, charity, hegemony, representation, history, and inequality - along with a hope that is neither naïve nor idealistic, but that remains committed to ideals of justice, reflexivity, and solidarity" (Grain \& Lund, 2016, p. 51). Using "critical hope", we validate NJCU student life experiences, which may include negative interactions with political elites and other governmental employees, but afford the tools, connections, and opportunities to take action.

\section{References}

Astin, A.W., Vogelgesang, L.J., Ikeda, E.K., \& J.A. Yee. (2000). How service learning affects students. Higher Education Research Institute. UCLA. Retrieved from https://heri.ucla.edu/PDFs/HSLAS/HSLAS.PDF

Benenson, J., \& Bergom, I. (2019). Voter participation, socioeconomic status, and institutional contexts in higher education. The Review of Higher Education, 42(4), 1665-1688. https://doi.org/10.1353/rhe.2019.0079

Bringle, R. G., \& Steinberg. (2010). Educating for informed community involvement. American Journal of Community Psychology, 46, 428-441. https://doi.org/10.1007/s10464-010$\underline{9340-\mathrm{y}}$

Brunson, R.K., \& Miller, J. (2005). Young black men and urban policing in the United States. The British Journal of Criminology, 46 (4), 613-640. https://doi.org/10.1093/bjc/azi093

Butin, D. W. (2006). The limits of service-learning in higher education. The Review of Higher Education, 29(4), 473-498. https://doi.org/10.1353/rhe.2006.0025

Candelario, G.E.B. (2018). Saber es poder: teaching and learning about social inequality in a New England Latin@community. In M. Castañeda and J. Krupczynski (Eds.). Civic engagement in diverse Latinx communities: Learning from social justice partnerships in action (pp. 179-198). New York: Peter Lang: 2018.

Carbado, D.W. (2017). From stopping black people to killing black people: The Fourth Amendment pathway to political violence. California Law Review, 105(1), 125-164. https://doi.org/10.15779/Z38GK24

Clear, T. R. (2008). The effects of high imprisonment rate on communities. Crime and Justice, 37, $97-$ 132. https://doi.org/10.1086/522360

Conley, P.A., \& Hamlin, M.L. (2009). Justice-learning: Exploring the efficacy with low-income, first

Journal of the Scholarship of Teaching and Learning, Vol. 21, No. 2, June 2021. josotl.indiana.edu 
generation college students. Michigan Journal of Community Service Learning, 16(1), 47-58. http://hdl.handle.net/2027/spo.3239521.0016.104

Doerr, N.M. (2015). Volunteering as othering: Understanding a paradox of social distance, obligation, and reciprocity. Partnerships: A Journal of Service-Learning and Civic Engagement, 6(2), 36-57.

Dong, S. (2019). The effects of first-generation status on student engagement and outcomes at liberal arts colleges. Journal of College Student Development, 60(1), 17-34. https://doi.org/10.1353/csd.2019.0001

Eyler, J., Giles, D.E. Jr., \& J. Braxton. (1997). The impact of service-learning on college students. Michigan Journal of Community Service Learning, 4(1), 5-15. http://hdl.handle.net/2027/spo.3239521.0004.101

Eyler, J., \& D.E. Giles Jr. (1999). Where's the learning in service-learning? San Francisco: JosseyBass.

Garza, A. (Guest) (2019, July 17). Getting Curious with Jonathan van Ness [Audio podcast]. Retrieved from https://www.stitcher.com/podcast/earwolf/getting-curious-with-jonathanvan-ness/e/62615864

Gelmon, S.B., Holland, B.A., Driscoll, A., \& Kerrigan, S. (2001). Assessing Service-Learning and Civic Engagement: Principles and Techniques. Campus Compact.

Godfrey, E.B., \& Cherng, H.Y.S. (2016). The kids are all right? Income inequality and civic engagement among our nation's youth. Journal of Youth and Adolescence, 45, 2218-2232. https://doi.org/10.1007/s10964-016-0557-4

Grain, K., \& Lund, D. (2016). The social justice turn: Cultivating 'critical hope' in an age of despair. Michigan Journal of Community Service Learning, 23(1), 45-59 https://doi.org/10.3998/mjcsloa.3239521.0023.104

Gramlich, J. (2019, July 2) What makes a good citizen? Voting, paying taxes, following the law top the list. Pew Research Center. Retrieved from https://www.pewresearch.org/facttank/2019/07/02/what-makes-a-good-citizen-voting-paying-taxes-following-the-law-top$\underline{\text { list/ }}$

Green, A.E. (2003). Difficult stories: Service-learning, race, class, and whiteness. College Composition and Communication, 55(2), 276-301.https://doi.org/ 10.2307/3594218

Hylton, M.E. (2018). The role of civic literacy and social empathy on rates of civic engagement among university students. Journal of Higher Education Outreach and Engagement, 22(1), 87-106.

Johnson, M.R. and Ferguson Jr., M. (2018). The role of political engagement in college students' civic identity: Longitudinal findings from recent graduates. Journal of College Student Development, 59(5), 511-527. https://doi.org/10.1353/csd.2018.0050.

Kanwischer, W., Lilgreen, A., \& Saralampi, M. (2015). Service learning as a college involvement and success strategy for underserved student populations. The Journal for Civic Commitment, 23. Retrieved from http://ccncce.org/articles/service-learning-as-a-college-involvement-andsuccess-strategy-for-underserved-student-populations/

Maxwell, J.A. (2005). Qualitative Research Design: An Interactive Approach (2 ${ }^{\text {nd }}$ ed.). Thousand Oaks, Cal.: Sage Publications, Inc.

Mills, C.W. (2000). The Power Elite. Oxford: Oxford University Press. https://doi.org/10.2307/2573526

Mirra, N., \& Garcia, A. (2017). Civic participation reimagined: Youth interrogation and innovation in the multimodal public sphere. Review of Research in Education, 41, 136158. https://doi.org/10.3102/0091732X17690121

Mitchell, T.D., Donahue, D.M., \& Young-Law, C. (2012). Service learning as a pedagogy of

Journal of the Scholarship of Teaching and Learning, Vol. 21, No. 2, June 2021. josotl.indiana.edu 
whiteness. Equity and Excellence in Education, 45(4), 612-629.

https://doi.org/ 10.1080/10665684.2012.715534

Naudé, L. (2015). On (un)common ground: Transforming from dissonance to commitment in a service learning class. Journal of College Student Development, 56(1), 84-102. https://doi.org/10.1353/csd.2015.0002

Patton, M.Q. (2002). Qualitative Research and Evaluation Methods (3 ${ }^{\text {rd }}$ ed.). Thousand Oaks, Cal.: Sage Publications, Inc.

Pearl, A.J., \& Christensen, R.K. (2017a). First-year student motivations for service-learning: An exploratory investigation of minority student perceptions. Journal of Higher Education Outreach and Engagement 21.4: 117-138.

Pearl, A.J., \& Christensen, R.K. (2017b). First-year student motivations for servicelearning: An Application of the Volunteer Functions Inventory. Michigan Journal of Community Service Learning, 23(2), 66-82. https://doi.org/10.3998/mjcsloa.3239521.0023.205

Rockenbach, A.N., Tuchmayer, J., \& Hudson, T. (2014). Enduring commitment to community service among diverse college students: Testing a multidimensional conceptual model. International Journal of Research on Service-Learning and Community Engagement, 2(1), 1-17.

Simons, L. \& Cleary, B. (2006). The influence of service learning on students' personal and social development. College Teaching, 54(4), 307-319. https://doi.org/ 10.3200/CTCH.54.4.307-319

Taylor, K. B., \& Baker, A.R. (2019). Examining the role of discomfort in collegiate learning and development. Journal of College Student Development, 60(2), 173-188. https://doi.org/ 10.1353/csd.2019.0017

Téllez, K. (2000). Reconciling service learning and the moral obligations of the professor. In C. O'Grady (Ed.) Integrating Service Learning and Multicultural Education in Colleges and Universities (pp. 71-91). Marwah, NJ: Lawrence Erlbaum Associates, Publishers.

The Center for Information and Research on Civic Learning and Engagement (2017, Apr 12). Millenials deeply uncertain about democracy post-election, but few believe it is in peril. The Center for Information and Research on Civic Learning and Engagement. Retrieved from https:// civicyouth.org/millenials-deeply-uncertain-about-democracy-post-election-butfew-believe-it-is-in-peril/?cat_id=14

The Center for Information and Research on Civic Learning and Engagement. (2018a). Historical youth voter turnout in national elections (Ages 18-29), 1972, 2016. The Center for Information and Research on Civic Learning and Engagement. Retrieved from https://civicyouth.org/quick-facts/youth-voting/

The Center for Information and Research on Civic Learning and Engagement. (2018b). Five takeaways on social media and the youth vote in 2018. The Center for Information and Research on Civic Learning and Engagement. Retrieved from https://civicyouth.org/fivetakeaways-on-social-media-and-the-youth-vote-in-2018/?cat_id=13

Yeh, T.L. (2010). Service-learning and the persistence of low-income, first-generation college students: An exploratory study. Michigan Journal of Community Service Learning, 16(2), 50-65. http://hdl.handle.net/2027/spo.3239521.0016.204

York, T.T. (2016). Exploring service-learning outcomes and experiences for low-income, firstgeneration college students: A mixed-methods approach. International Journal of Research on Service-Learning and Community Engagement. 4.1: 309-342.

Journal of the Scholarship of Teaching and Learning, Vol. 21, No. 2, June 2021. josotl.indiana.edu 